\title{
$50 \mathrm{kHz}$ 체장어군탐지기용 분할 빔 음향 변환기의 개발
}

\section{이대재 ${ }^{*} \cdot$ 이원섭 ${ }^{1}$ \\ 부경대학교 해양생산시스템관리학부, ${ }^{1}$ 부산광역시 강서구청 \\ Development of Split-beam Acoustic Transducer for a 50 kHz Fish Sizing Echo Sounder}

\author{
Dae-Jae Lee* and Won-Sub Lee ${ }^{1}$ \\ Division of Marine Production System Management, Pukyong National University, \\ Busan 608-737, Korea \\ ${ }^{1}$ Gangseo District Office, Busan Metropolitan, Busan 618-701, Korea
}

\begin{abstract}
An improved split-beam transducer for a $50 \mathrm{kHz}$ fish-sizing echo sounder was developed. The main objective of this study was to minimize the side lobe level in the beam pattern and the distance between acoustic centers for adjacent transducer quadrants in the geometrical arrangement of array elements while maintaining a given number of transducer elements and beam width. To achieve these goals, a 32-element planar array transducer $(6 \times 6$ array with one element in each corner missing) was designed using the Dolph-Chebyshev shading function to suppress side lobes in the array beam pattern and fabricated by arranging the inter-element spacing to be substantially equal to half the wavelength using the transducer element of 0.4 times the wavelength in diameter. The performance characteristics of this split-beam transducer were evaluated in the experimental water tank of $5 \mathrm{~m} \times 5 \mathrm{~m} \times 6 \mathrm{~m}$ (length $\times$ height $\times$ width). In this study, the design goal of the beam width and side lobe level for transmitting a beam pattern was initially set at $21^{\circ}$ and $-30 \mathrm{~dB}$, respectively. However, the measured beam width at $3 \mathrm{~dB}$ was $21^{\circ}$ in both directions with side lobe levels of $-24.7 \mathrm{~dB}$ in the horizontal plane and $-25.6 \mathrm{~dB}$ in the vertical plane. The averaged beam width at $-3 \mathrm{~dB}$ of the receiving beam patterns for four receiving quadrants was $31.4^{\circ}$. The transmitting voltage response was $161.5 \mathrm{~dB}$ (re $1 \mu \mathrm{Pa} / \mathrm{V}$ at $1 \mathrm{~m}$ ) at $50.23 \mathrm{kHz}$ with a bandwidth of $2.16 \mathrm{kHz}$, and the averaged receiving sensitivity for four receiving quadrants was $-178.13 \mathrm{~dB}(\mathrm{re} 1 \mathrm{~V} / \mu \mathrm{Pa})$ at $49.8 \mathrm{kHz}$ with a bandwidth of $2.64 \mathrm{kHz}$.
\end{abstract}

Key words: Split beam transducer, Side lobe suppression, Transmitting voltage response, Receiving sensitivity, Fish sizing echo sounder

\begin{abstract}
서 론
현재 우리나라를 비롯하여 북미, $\mathrm{EU}$, 일본과 같은 세계의 주 요 수산국에서는 자국의 수역에 분포하는 어업생물자원을 효 율적으로 관리하기 위해 총허용어획량(total allowable catch, $\mathrm{TAC}$ ) 제도를 시행하고 있다. 이들 나라에서는 TAC 제도의 시 행과 관련하여 어업자에게 할당한 어획량이 소진되는 과정을 다양한 형태로 모니터링하고 있고, 또한, 이와 병행하여 연근해 어장에서 어획되는 부수 어획물의 처리와 관련한 기준을 마련 하여 어업자가 목적하는 어종이 아니거나, 상업성이 없는 소형 의 어업생물이 어획될 때, 이들이 바다에 폐기되는 것을 방지하 기 위한 방안의 수립에 많은 노력을 경주하고 있다(FAO, 2009). 이와 같은 문제를 해결하기 위한 방법의 하나로서 세계 여러 나 라에서는 어로 현장에서 대상 어류의 체장을 직접 추정할 수 있
\end{abstract}

*Corresponding author: daejael@pknu.ac.kr
는 체장어군탐지기(fish sizing echo sounder)를 보급하는 데 많 은 지원을 행하고 있다(MacLennan et al., 1995; Sawada et al., 2004). 그러나, 우리나라에서는 이 시스템의 기반이 되는 음향 변환기 설계 및 표적추적에 관한 신호처리 기술이 아직 상업적 으로 확립되지 않아 국산화가 지연되고 있는 실정이다(Lee et al., 2001). 우리나라 주변해역에서 조업하는 대형 선망, 대형 트 롤 및 대형 기선저인망 어선 등에 있어서는 어획대상 어종에 대 한 체장 조성을 실시간으로 파악하기 위한 목적으로 주로 유럽 이나 북미에서 사용하고 있는 $38 \mathrm{kHz}$ 와 $70 \mathrm{kHz}$ 용 split beam 방식의 체장어군탐지기가 널리 보급되고 있다(Simrad , 2008). 그러나, 최근 들어 우리나라, 일본, 대만, 중국 등을 비롯한 동남 아 여러 나라에서는 과거의 조업경험으로부터 많은 정보가 축적 된 $50 \mathrm{kHz}$ 용 체장어탐 시스템에 대한 요구가 점차 부각됨에 따 라 이들 수요를 충족시키기 위한 체장 어탐 시스템의 개발이 우 리나라를 비롯한 일본, 서구 등에서 활발하게 진행되고 있다. 일 반적으로 음향을 이용하여 어업생물의 체장을 추정하기 위한 4 
분할 빔 음향 변환기를 설계할 때, 가장 먼저 고려해야 할 사항 은 음향 어뢰(torpedo) 시스템에서와 같이 송신 지향성의 빔 패 턴에 대한 sidelobe 레벨의 적극적인 억제와 수신 지향성을 발생 시키는 4 분할 진동자 그룹의 음향학적 중심 사이의 간격을 최 소화시키는 기술의 개발이다. 그러나, 이들 두 개의 문제는 시 스템의 탐지능력과 매우 밀접하게 연관되어 있기 때문에 목적 하는 어장환경에 적합한 설계 목표를 설정하는 것이 필요하다 (Ehrenberg, 1981; Lee et al., 2001; Park et al., 2004).

본 연구에서는 우리나라 연근해 어장의 수심범위를 고려하 여 Dolph-Chebyshev shading 기법(Dolph, 1946)을 이용하여 빔 폭과 sidelobe 레벨을 최적화하여 어류의 위치추적 dynamic range를 증대시키고, 4 분할된 수신 진동자 그룹의 음향중심(위 상중심) 간격을 한 파장 이하로 최소화함으로서 mainlobe 지 향각내에서 유영하는 모든 어류의 탐지가 가능한 $50 \mathrm{kHz}$ split beam 음향 변환기를 설계, 개발하였다.

\section{재료 및 방법}

\section{Split beam transducer의 설계}

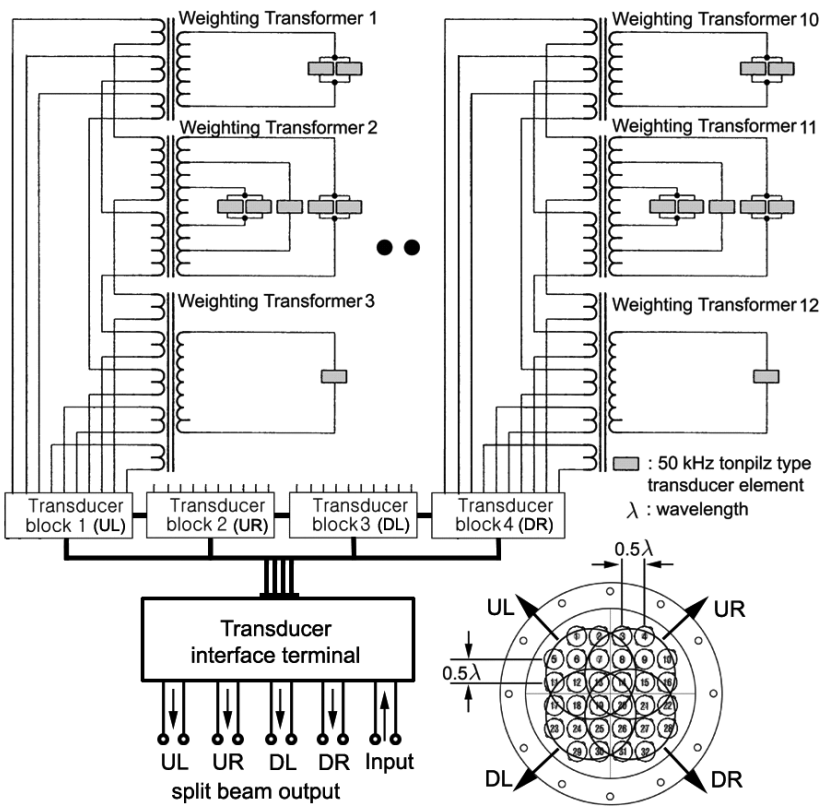

Fig. 1. A layout for weighting transformers, transducer interface terminal, four receiving transducer quadrants and planar array of 32 identical transducer elements arranged with the inter-element spacing being substantially equal to half the wavelength.

체장어군탐지기를 사용하여 해중에 분포하는 어류의 체장 을 추정할 때, 송신 펄스가 발사될 때마다 탐지해 낼 수 있는 어 류의 개체 수와 체장 추정의 정밀도 등은 음향 변환기의 지향성 패턴에 대한 빔 폭, sidelobe 레벨, 수신 진동자 블록의 음향중심 간격 등에 의해 결정된다. 본 연구에서는 우리나라를 비롯한 전 세계에 공급되고 있는 체장어군탐지기에서 채용하고 있는 기존
의 4 분할 split beam 방식보다 어류의 탐지영역을 획기적으로 개선할 목적으로 군용 어뢰에서 채택하고 있는 가중회로기법을 적용하여 음향 변환기를 설계, 개발하였는데, 그 음향 진동소자 (Lee et al., 2010)의 배열 및 가중회로에 대한 모식도는 Fig. 1과 같다. Fig. 1에서 알 수 있는 바와 같이 split beam 음향 변환기 는 $6 \times 6$ 배열에서 네 모퉁이의 진동소자를 각각 하나씩 제거하 여 총 32 개로 구성하고, 각 진동소자를 모두 반파장의 간격으로 배열한 원형에 근사한 형상을 하고 있다. 특히, 송신시에는 송신 가중회로에 접속된 모든 진동소자를 사용하여 해중에 음파를 방 사하는데, 본 연구에서는 송신 지향각의 목표치를 $21^{\circ}$, 첫 번째 sidelobe 레벨을 $-30 \mathrm{~dB}$ 로 설정하여 송신 가중회로를 설계하였 고, 수신시에는 4 개의 분할된 수신 진동자 블록에 대한 음향중 심간격의 설계 목표치를 한 파장으로 설정하여 수신가중회로를 설계하였다. 또한, 이렇게 설계, 제작된 음향진동소자, 송신 및 수신 가중회로, 차동전치증폭회로 등을 진동자 블록내부에 함께 수납하여 음향 변환기를 제작함으로서 신호대 잡음비 (signal to noise ratio, SNR)를 개선시키고자 하였다.

\section{송파전압감도 및 chirp 펄스신호의 응답특성 측정}

$50 \mathrm{kHz}$ split beam 음향 변환기에 대한 공기중 및 수중에 있어서의 전기적인 임피던스(또는 어드미턴스)는 정밀 $\mathrm{LCR}$ meter(Model 7600, QuadTech, USA)를 이용하여 측정하였다. 음향 변환기의 송파감도(transmitting voltage response, 이하 TVR이라 한다.)는 LFM(linear frequency modulation) 신호를 이용하여 실험수조 $(\mathrm{L} \times \mathrm{B} \times \mathrm{D}, 5 \mathrm{~m} \times 6 \mathrm{~m} \times 5 \mathrm{~m})$ 에서 측정하였다. $\mathrm{LFM}$ 신호는 PC 상에서 발생시켜 RS-232C interface를 거쳐 임 의파형발생기(Model 33120A, HP, USA)의 메모리에 전송시킨 후, 실험시 호출하여 이용하였다. 본 연구에서 이용한 up-chirp 신호 $S(t)$ 는

$$
S(t)=\operatorname{Arect}\left(\frac{t}{T}\right) \sin \left(2 \pi f_{s} t+\pi \alpha t^{2}\right)
$$

로서 정의되는 $\mathrm{LFM}$ 펄스신호인데, 여기서, $A$ 는 chirp 펄 스신호의 진폭, $f_{S}$ 는 chirp 펄스신호의 개시주파수 (start frequency)로서, $f_{S}=f_{0}-\frac{\Delta f}{2}$ ( $f_{0}$ : 중심주파수, $\Delta f:$ chirp 신호의 주파수 대역폭)이다. 또한, $\alpha$ 는 chirp 펄스신호의 sweep rate 로서, chirp 펄스의 폭을 $T$ 라 할 때, $\alpha=\frac{\Delta f}{T}$ 이다. 또한 $0 \leq t \leq T$ 이면, $\operatorname{rect}\left(\frac{t}{T}\right)=1$ 이고, $\mathrm{t} \leq 0$ 또는 $\mathrm{t} \geq \mathrm{T}$ 이면, $\operatorname{rect}\left(\frac{t}{T}\right)=0$ 인 함 수이다.

실험은 Fig. 2에서와 같이 펄스폭 $T=1.25 \mathrm{~ms}, f_{S}=50 \mathrm{kHz}$, $\Delta f=40 \mathrm{kHz}$ 의 up-chirp 신호를 생성시켜 전력증폭기(Model $2713, \mathrm{~B} \& \mathrm{~K}$, Denmark)를 통해 증폭한 후, 이 신호를 matching network을 경유하여 음향 변환기에 인가하였다. 음향 변환기 에서 발사된 송신 펄스신호는 수중청음기(Model 8105, B\&K, Denmark 및 C304, Cetacean research technology, USA)을 통해 수신하였고, 이 신호를 charge amplifier(Model 2635, B\&K, Denmark) 및 measuring amplifier(Model 2610, B\&K, 


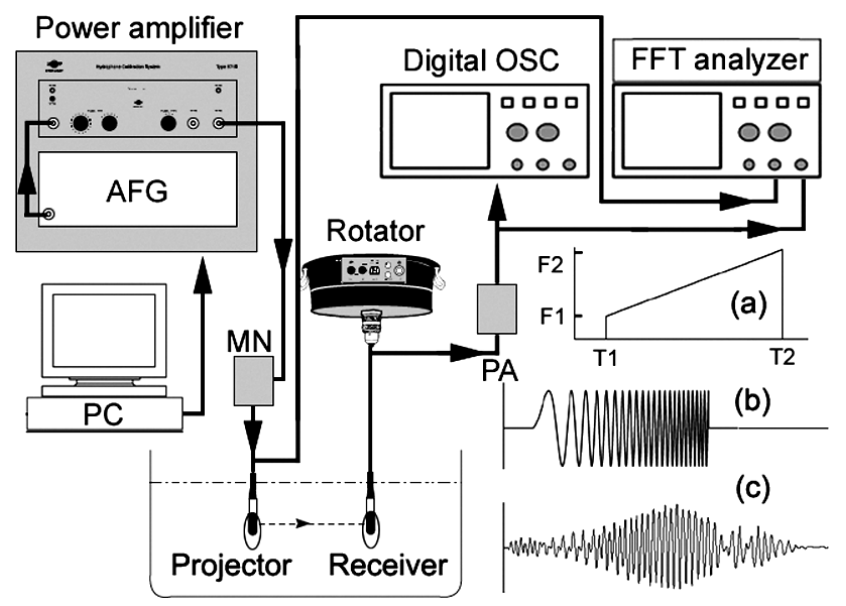

Fig. 2. Schematic diagram of the experimental setup for measuring the underwater performance characteristics of a developed $50 \mathrm{kHz}$ split-beam transducer. (a) Diagram of time and frequency in LFM signal, (b) Transmitted chirp pulse, (c) Received chirp response.

Denmark)를 경유하여 digital storage oscilloscope(DS-1230, Ezdigital, Korea) 및 FFT analyzer(Model 3525, AND, Japan) 에 입력하였다. 실험은 송신 및 수신신호를 관찰하면서 FFT analyzer를 통해 송신 및 수신 신호에 대한 시간응답신호와 주파 수 스펙트럼을 각각 측정, 수록하고, 이들 주파수 스펙트럼을 비 교, 분석하여 $40-60 \mathrm{kHz}$ 주파수범위에 대한 송파전압감도를 구 하였다.

한편, 수파감도(receiving sensitivity, 이하 SRT라 한다.)는 송파감도와 동일한 방법으로 측정하였는데, 먼저, 광대역 송수 파기(Model R209, Airmar, USA)를 사용하여 chirp 펄스신호를 송신하고, 본 연구에서 개발한 $50 \mathrm{kHz}$ split beam 음향 변환기 와 수중청음기를 통해 송파신호를 각각 수신하였다. 이들 신호 를 digital storage oscilloscope 및 FFT analyzer에 입력한 후, 이 들 송신 및 수신 신호에 대한 시간응답신호와 주파수 스펙트럼 을 각각 측정, 수록하고, 이들 주파수 스펙트럼을 비교, 분석하 여 수파감도를 구하였다.

\section{음향 변환기의 송신 및 수신 지향성 특성의 측정}

본 연구에서 개발한 $50 \mathrm{kHz}$ split beam 음향 변환기의 수평 및 수직방향에 대한 송신지향성 패턴은 (2)식에 의해 구하였다. 즉, split beam 음향 변환기에서 $x$ 축 방향으로 $N$ 개, $y$ 축 방향으 로 $M$ 개의 음향소자가 각각 $d x, d y$ 의 간격으로 배열되어 있을 때, 그 음압 지향성 패턴 $D(\theta, \varphi)$ 는 (2)식에 의해 구할 수 있다 (Balanis, 1997; Foote, 1990; Quaji, 1982; Ziomeck, 1985).

$$
D(\theta, \varphi)=\frac{\sum_{m=1}^{M} \sum_{n=1}^{N} C_{m n} \mathrm{e}^{j k d_{x y}}}{\sum_{m=1}^{M} \sum_{n=1}^{N} C_{m n}} \cdot D_{S}(\theta, \varphi)
$$

여기서, $\theta, \varphi$ 는 각각 음축으로부터 $x$ 축 및 $y$ 축 방향으로 측
정한 방향각, $C_{m n}$ 은 $x$ 축 방향에 대한 $N$ 개 진동소자와 $y$ 축 방향 에 대한 $M$ 개의 진동소자에 의해 구성되는 배열소자 matrix에 대한 Dolph-Chebyschev shading의 가중치, $d_{x y}$ 는 $d_{x y}=\frac{1}{2}$ ( $2 m$ $M-1) d x \sin \theta+\frac{1}{2}(2 n-N-1) d y \sin \varphi$ 이고, $D_{S}(\theta, \varphi)$ 는 음향 소자가 반경이 $\mathrm{a}$ 인 원형 진동소자인 경우, (3)식에 의해 구할 수 있다.

$$
D_{S}^{2}(\theta, \varphi)=b(\theta, \varphi)=\left|\frac{2 J_{1}(\mathrm{Z})}{\mathrm{Z}}\right|^{2}
$$

여기서, $J_{1}(*)$ 은 제 1 종 1 차 Bessel 함수 (the first-order Bessel function of the first kind), $\mathrm{Z}=k a \sin \alpha$ 이고, $k$ 는 파수 (wavenumber)로서 $k=\frac{2 \pi}{\lambda}$ ( $\lambda$ : 파장)이고, $\alpha$ 는 $\alpha=\cos ^{-1}(\cos \theta$ $\cdot \cos \varphi$ ) 이다.

가중회로 (weighting transformer)의 설계 및 제작

본 연구에서 설계, 제작한 송신 및 수신 가중회로의 모식도 는 Fig. 3과 같다. Fig. 3에서 split beam 음향 변환기의 4 분할 진동자 그룹 중에서 $\mathrm{UL}$ 의 가중 transformer XFMR1, XFMR2, $\mathrm{XFMR3}$ 에 인가되는 전력을 각각 $P_{P 1}, P_{P 2}, P_{P 3}$ 라 하면, 이들 transformer에 인가되는 전력 $P_{P}$ 는

$$
P_{p}=\sum_{x=1}^{n} P_{p x}
$$

이 되고, split beam 음향 변환기의 4 분할 진동자 전체에 공급되 는 총 전력은 $4 P_{P}$ 이 된다. Fig. 3 의 각 transformer에서의 손실 을 무시하면, 이들 transformer의 1 차측으로 공급되는 모든 전 력은 2 차측에 접속된 진동소자에서 모두 소비되므로. 각각의 XFMR1, XFMR2, XFMR3에 대한 2 차측의 소비전력을 $P_{S 1}$, $P_{S 2}, P_{S 3}$ 라 할 때, 이들 transformer에서 소비되는 전력 $P_{S}$ 는

$$
P_{s}=P_{p}=\sum_{x=1}^{n} P_{s x}=\sum_{x=1}^{n} P_{p x}
$$

으로서 공급전력과 같게 된다. 이 때, XFMR1의 1 차측을 통해 2 차측의 진동소자 13 에 공급되는 전압을 $V_{20}, \mathrm{XFMR2}$ 를 통해 병렬 접속 진동소자 7 과 12 에 공급되는 전압을 $V_{21}$, 진동소자 6 에 공급되는 전압을 $V_{22}$, 병렬 접속 진동소자 1 과 5 에 공급되는 전압을 $V_{23}, \mathrm{XFMR3}$ 을 통해 병렬 접속 진동소자 2와 11에 공급 되는 전압을 $V_{31}$, 또한, 각 transformer에 접속된 모든 진동소자 의 임피던스가 모두 동일하고, 그 임피던스를 Z라 하면

$$
\begin{aligned}
& P_{p 1}=P_{s 1}=\frac{V^{2}{ }_{11}}{\mathrm{Z}} \\
& P_{p 2}=P_{s 2}=\frac{2 V_{21}^{2}+V_{22}^{2}+2 V_{23}^{2}}{\mathrm{Z}} \\
& P_{p 3}=P_{s 3}=\frac{2 V_{31}^{2}}{\mathrm{Z}}
\end{aligned}
$$


이 된다. 본 연구에서는 Dolph-Chebyshev 배열 기법을 이용하 여 평면 배열 split beam 음향 변환기의 빔 폭과 측엽 준위를 최 적화할 목적으로 허용 측엽 준위와 변환 소자의 간격을 입력 변 수로 설정하여 수치 시뮬레이션을 행하고, 송파기의 가중회로 를 설계, 제작하기 위한 최적의 가중치를 구하였다. 특히, 본 연 구에서는 목표 sidelobe 레벨을 $-30 \mathrm{~dB}$ 로 설정하고, 이 sidelobe 레벨을 만족하는 2 차원 평면 배열의 각 진동 소자에 인가해야 할 상대적인 진폭 가중치를 구하였다. 즉, UL에 배치된 각 진 동소자의 상대적인 진폭 가중치는 $\mathrm{a}=1.0, \mathrm{~b}=0.7174, \mathrm{c}=0.4565$, $\mathrm{d}=0.25, \mathrm{e}=0.3478$ 이었고, 이 값을 기초로 하여 가중회로를 설계 하였다.

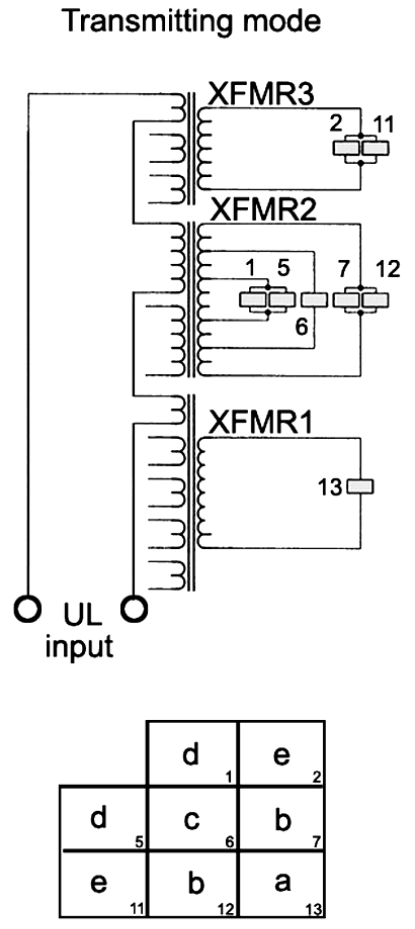

(a)

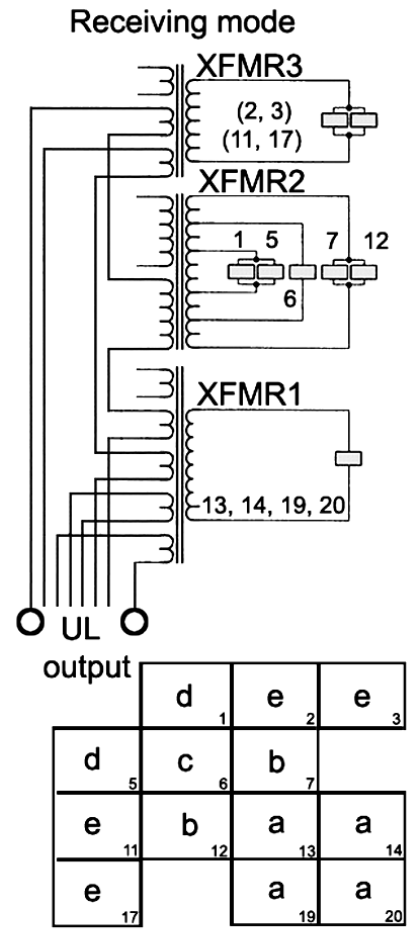

(b)
Fig. 3. Block diagrams showing the electrical connection for transmitting (a) and receiving modes (b) between weighting transformers and transducer elements consisting of the UL quadrant of split beam transducer.

본 연구에서는 split beam 음향 변환기의 입력 임피던스 설 정치를 $400 \mathrm{ohm}$, 전기출력 설정치를 $400 \mathrm{~W}$ 로 하여 UL의 가 중 transformer XFMR1, XFMR2, XFMR3에 대한 1 차측 및 2 차측 코일에 대한 입력 임피던스와 인덕턴스를 구하고, 이들 값 을 만족하도록 가중 transformer를 설계, 제작하였다. 또한 설계 에 사용한 EI core(TDK, Japan)의 AL값과 XFMR1, XFMR2, XFMR3의 각각에 대한 1 차측 코일의 인덕턴스 $(L)$ 를 이용하 여 $N=\sqrt{\frac{L}{A L}}$ 의 관계식으로부터 권선수 $N$ 을 구하고, 이 권선수와 각 송신측 권선비로부터 2 차측 코일의 권선수를 산출하여 가중 transformer를 제작하였다.
한편, split beam 음향 변환기의의 4 분할 진동자 그룹 중에 서 UL에 대한 가중 transformer XFMR1, XFMR2, XFMR3에 대한 1 차측 수신 코일의 인덕턴스 및 권선수의 설계는 먼저 각 가중 transformer에 접속된 각 진동자 그룹에 대한 송신 권선비 $\left(N_{T}\right)$ 와 수신 권선비 $\left(N_{R}\right)$ 의 곱, 즉 $N_{T R}=N_{T} \times N_{R}$ 의 값을 일정한 목표치 $\left(N_{T R}=2.5\right)$ 로 설정하여 가중회로를 설계, 제작하였다. 즉, XFMR1, XFMR2, XFMR3의 transformer 별로 송신 권선비와 수신 권선비가 일정하게 유지되도록 하여 수신 에너지의 음향 중심이 수신 진동자 그룹의 중앙에 위치하도록 하였다. 따라서, Fig. 3 에서 XFMR1에 접속된 진동자 $13,14,19,20$ 에 대한 송 신 모드의 총 권선비를 $N_{a T 1}, 2$ 차측 총 권선수를 $N_{b T 1}, \mathrm{XFMR2}$ 에 접속된 진동자 7 과 12 , 진동자 6 , 진동자 1 과 5 에 대한 송신 모드의 총권선비를 $N_{a T 2}, 2$ 차측 총권선수를 $N_{b T 2}, \mathrm{XFMR3}$ 에 접속된의 진동자 2 와 3 , 진동자 11 과 17 에 대한 송신 모드의 총 권선비를 $N_{a T 3}, 2$ 차측 총권선수를 $N_{b T 3}$ 라 할 때, 이들 XFMR1, $\mathrm{XFMR2,XFMR3의} \mathrm{수신측} \mathrm{코일의} \mathrm{인덕턴스} L_{R 11}, L_{R 21}, L_{R 31}$ 은

$$
\begin{aligned}
& L_{R 11}=\left(\frac{N_{T R}}{N_{a T 1}} \cdot \frac{N_{b T 1}}{4}\right)^{2} \cdot A L \\
& L_{R 21}=\left(\frac{N_{T R}}{N_{a T 2}} \cdot N_{b T 2}\right)^{2} \cdot A L \\
& L_{R 31}=\left(\frac{N_{T R}}{N_{a T 3}} \cdot \frac{N_{b T 3}}{2}\right)^{2} \cdot A L
\end{aligned}
$$

에 의해 구하여 수신 진동자에 대한 가중 transformer를 제작하 였다.

\section{결과 및 고찰}

split beam 음향 변환기의 진동소자 배열, 가중회로 및 구조적 특성

본 연구에서 설계, 개발한 $50 \mathrm{kHz}$ split beam 음향 변환기의 진동소자의 배열, 가중회로 module 및 음향 변환기의 실제적인 사진은 Fig. 4와 같다. Fig. 4에서 (a)는 평면배열 진동소자 그룹 의 상부에 장치된 가중회로 및 전치증폭기 module을 나타낸 것 이고, (b)는 음향 window를 포함하는 split beam 음향 변환기의 전체적인 구조를 나타낸 것이다. 이 음향 변환기의 작동 주파수 는 $50 \mathrm{kHz}$ 이고, Fig. 4 (b)에서 $50 \mathrm{kHz}$ 의 tonpilz type 진동소자 가 배열된 전면 진동체의 직경과 높이는 각각 $13.0 \mathrm{~cm}, 6.1 \mathrm{~cm}$ 이고, Dolph-Chebyshev 배열 기법에 의해 도출된 파리미터를 토대로 설계, 제작된 가중회로 및 전치증폭기가 수납된 후면 원 통 구조물의 직경 및 높이는 각각 $22 \mathrm{~cm}, 6.3 \mathrm{~cm}$ 로서 전체적인 높이는 $12.4 \mathrm{~cm}$, 총 공기 중에서의 총 중량은 약 $10.5 \mathrm{~kg}$ 이다.

Fig. 4 (a)에 나타낸 가중회로 module은 음향 변환기의 sidelobe를 효과적으로 억제하기 위해 먼저 개개의 진동체를 음 향 window상에 배열할 때, 그 형상을 사각형보다는 원형에 가 


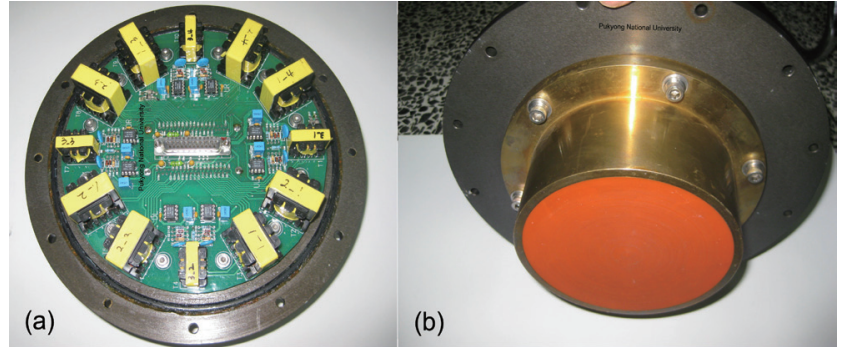

Fig. 4. Photographs for an opened sensor module for four transducer quadrants with pre-amplifiers electronics and amplitude weighting transformers installed on the PCB (a) and a $50 \mathrm{kHz}$ split-beam transducer assembly developed in this study (b).

깝게 배치함으로서 형상에 의한 기계적인 가중구조 효과를 얻었 다. 그 후, 여기에 Dolph-Chebyshev shading 함수를 이용하여 도출한 전기적인 가중회로 파리미터를 토대로 설계, 제작한 가 중 transformer를 PCB 상에 전치증폭기와 함께 장착하고, 이것 을 음향 변환기 내부에 수납함으로서 신호대 잡음비를 개선하 고자 하였다. 본 연구에서 개발한 split beam 음향 변환기에서와 같이 많은 소형의 초음파 소자를 사각의 정방형으로 평면 배열 하여 진폭 shading 없이 수밀 몰딩한 후, 송파기로서 사용할 때, 그 지향성 패턴에서 첫 번째의 sidelobe level은 약 $-13 \mathrm{~dB}$ 정도 가 된다. 그러나, 동일한 수의 초음파 소자를 원형에 가까운 형 태로 배열하여 사용하면 그 sidelobe level 값은 약 $-18 \mathrm{~dB}$ 정도 를 나타내어 sidelobe level이 억제되는 효과가 있다. 본 연구에 서는 이 점에 주목하여 $6 \times 6$ 평면 배열 패턴에서 사각의 네모서 리에 위치하는 초음파 소자를 하나씩 제거한 총 32 개의 tonpilz 형 소자를 사용함으로써 배열 형상에 의한 기계적인 가중치가 자동적으로 부여되도록 한 후, 반복적인 수치 시뮬레이션을 통 해 얻은 Dolph-Chebyshev 가중회로에 대한 설계 파라미터를 토대로 가중 transformer를 자체적으로 설계, 제작하였다. 즉, 배열형상을 사각의 정방형 구조에서 원형 구조로 변환할 때, 배 열의 끝단으로 갈수록 진동면이 좁아져 송파 에너지의 기여도 가 작아짐으로써 나타나는 형상학적인 amplitude weighting의 효과를 설계에 반영하였다. 여기서, 가중 transformer는 시중에 서 구입이 용이하면서도 공급전력의 용량을 고려하여 TDK EI core를 사용하여 구현하였는데, Fig. 3에서 XFMR1와 XFMR2 는 PC40EI33/29/13 core로서, 또한, XFMR3는 PC40EI25 로서 설계, 제작하였다. 이들 $\mathrm{EI}$ core의 $A L\left(\mathrm{nH} / \mathrm{N}^{2}\right)$ 값은 $\mathrm{air}$ gap length을 적절하게 조정함으로써 요구되는 인덕턴스를 얻 었는데, $\mathrm{PC} 40 \mathrm{EI} 33 / 29 / 13$ core에 대한 $A L$ 값은 $190 \mathrm{nH} / \mathrm{N}^{2}$, $\mathrm{PC} 40 \mathrm{EI} 25$ 에 대한 $A L$ 값은 $80 \mathrm{nH} / \mathrm{N}^{2}$ 이 되도록 air gap을 유지 하였고, transformer의 coil 직경은 전력 증폭기가 연결되는 송신 측 코일에 대해서는 직경 $0.4 \mathrm{~mm}$, 진동자측과 수신측에 대해서 는 직경 $0.2 \mathrm{~mm}$ 코일을 사용하였다. 또한, 본 연구에서는 split beam 어군탐지기를 실제 사용하고 있는 현장 어업자들의 요구 를 고려하여 크기(직경)가 반파장 $(3 \mathrm{~cm})$ 보다 작은 직경 $12 \mathrm{~mm}$
의 $50 \mathrm{kHz}$ tonpilz형 진동소자를 독자적으로 개발하여 사용하였 고, 음향 window의 재질로서는 polyurethane을 사용하였다.

\section{split beam 음향 변환기의 어드미턴스 특성}

본 연구에서 개발한 Fig. 4의 $50 \mathrm{kHz}$ split beam 음향 변환기 에 대한 수중에서의 conductance 및 susceptance를 측정한 결 과는 Fig. 5 와 같다. Fig. 5 에서는 송신 진동자 블록과 DR, DL, UR 및 UL의 수신 진동자 블록에 대한 어드미턴스의 측정 결과 를 상호 중첩시켜 나타낸 결과로서, 종축은 conductance $(\mu \mathrm{s})$ 및 susceotance $(\mathrm{ms})$ 이고, 횡축은 주파수 $(\mathrm{kHz})$ 이다. Fig. 5에서 송 신 진동자 블록의 수중에 대한 최대 conductance를 나타내는 주파수는 $49.85 \mathrm{kHz}$ 이었고, 이 주파수에 대한 conductance 및 suceptance 값은 각각 $363.19 \mu s,-2.27 \mathrm{~ms}$ 이었다.

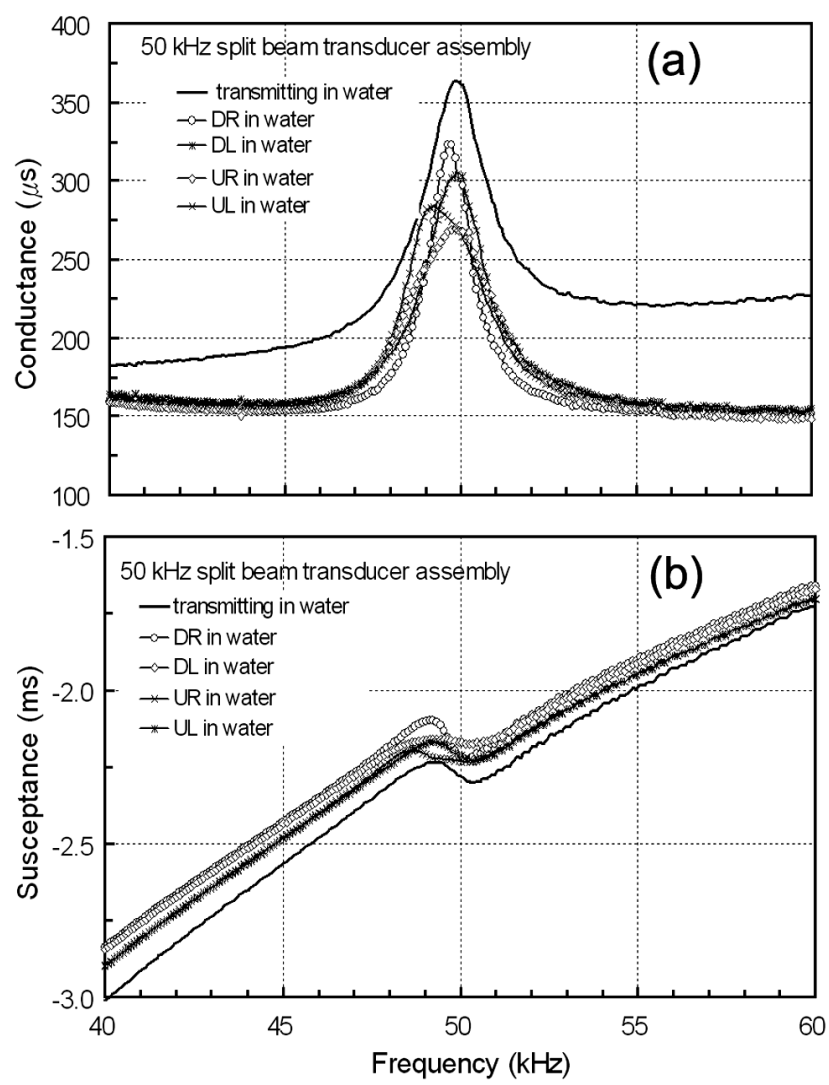

Fig. 5. Electrical conductance (a) and susceptance (b) for UL, UR, DL and DR quadrants of a developed $50 \mathrm{kHz}$ split-beam transducer in water.

한편, 수신 진동자 블록에 대해서는 먼저 $\mathrm{DR}$ 블록의 경우, 최 대 conductance를 나타내는 주파수는 $49.64 \mathrm{kHz}$ 이었고, 이 주 파수에 대한 conductance 및 suceptance 값은 각각 $322.71 \mu s$, $-2.15 \mathrm{~ms}$ 이었다. DL 블록의 경우에는 최대 conductance 가 출현하는 주파수가 $49.85 \mathrm{kHz}$ 이었고, 이 주파수에 대한 
conductance 및 suceptance 값은 각각 $303.65 \mu s,-2.21 \mathrm{~ms}$ 이었 다. 한편, UR 블록에 대한 최대 conductance는 DL 블록과 같 이 $49.85 \mathrm{kHz}$ 에서 출현하였고, 이 주파수에 대한 conductance 및 suceptance 값은 각각 $269.4 \mu s,-2.17 \mathrm{~ms}$ 이었다. UL 블록 의 경우에 있어서는 최대 conductance가 다른 블록보다 약간 낮 은 $49.24 \mathrm{kHz}$ 에서 출현하였고, 이 주파수에 대한 conductance 및 suceptance 값은 각각 $283.37 \mu s,-2.22 \mathrm{~ms}$ 이었다. 음향 변 환기의 송파전압감도는 conductance, 지향성지수(directivity index), 전기음향변환효율 등에 의해 결정되지만, 그 중에서 주 파수에 따른 conductance의 변동이 송파전압감도의 주파수 특 성을 결정하는 중요한 요소가 된다(Wilson, 1991). Fig. 5에서 $50 \mathrm{kHz}$ split beam 음향 변환기의 송신 진동자 블록에 대한 최대 conductance가 나타내는 주파수는 설계 목표치인 $50 \mathrm{kHz}$ 와 거 의 근사한 특성을 나타내었다. 또한, 수파감도의 주파수 특성은 주파수에 따른 임피던스와 송파전압감도의 변동에 의해 결정되 는데, Fig. 5에서 수신 진동자 블록에 대한 conductance는 DR, $\mathrm{DL}, \mathrm{UL}, \mathrm{UR}$ 의 순으로 감소하는 특성을 나타내었다.

Split beam 음향 변환기의 송파감도

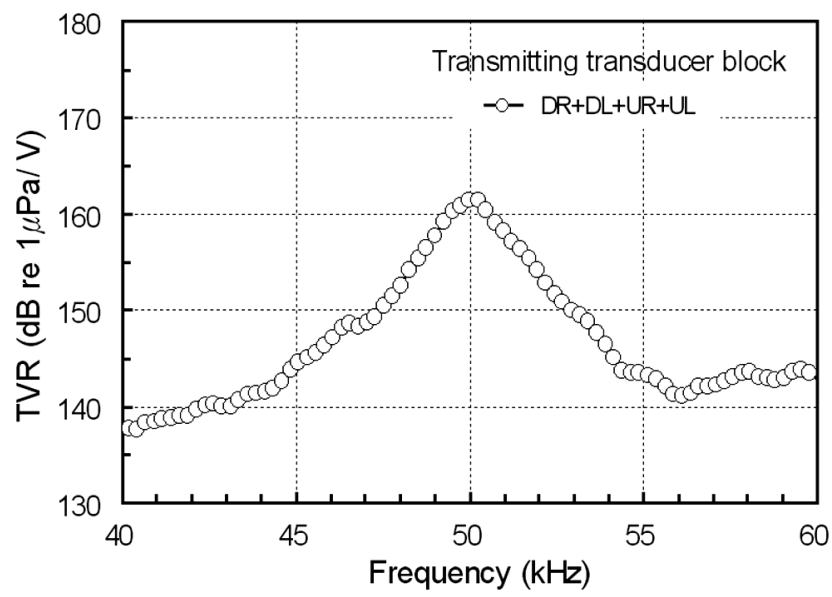

Fig. 6. Transmitting voltage response (TVR) of a developed $50 \mathrm{kHz}$ split-beam transducer.

본 연구에서 설계, 개발한 split beam 음향 변환기의 송파전 압감도 TVR(dB re $1 \mu \mathrm{Pa} / \mathrm{V}$ at $1 \mathrm{~m})$ 를 측정 결과는 Fig. 6 과 같 다. Fig. 6에서 종축은 TVR $(\mathrm{dB})$ 이고, 횡축은 주파수 $(\mathrm{kHz})$ 이 다. Fig. 6의 TVR은 Fig. 4에서와 같이 음향 변환기에 공급되는 chirp 펄스신호의 주파수 스펙트럼과 수중청음기를 이용하여 측 정한 음향 변환기에서 송출되는 송파파형의 주파수 스펙트럼을 이용하여 다음 식으로부터 산출하였다.

$$
T V R(f)=20 \log \left(\frac{E_{R}(f)}{E_{T}(f)}\right)-M R(f)+20 \log (R)
$$

여기서, $E_{T}(f)$ 는 송신 chirp 펄스신호의 주파수 스펙트럼, $E_{R}(f)$ 는 음향 변환기에서 송출되는 chirp 송신펄스신호를 음축
상 $R$ 만큼 떨어진 위치에서 수중청음기를 이용하여 측정한 수파 신호의 주파수 스펙트럼, 또한, $M_{R}(f)$ 는 수중청음기의 수파감도 (dB re 1V/ $\mu \mathrm{Pa}$ ), $f$ 는 주파수이다 (Hughes et al., 1969; Hughes, 1998). Fig. 6에서 송파전압감도의 주파수 의존성은 Fig. 5 (a)의 split beam 음향 변환기의 conductance에 대한 주파수 의존성과 거의 일치하는 경향을 나타내고 있다. Fig, 6 에서 최대의 송파전 압감도를 나타내는 공진주파수는 $50.23 \mathrm{kHz}$ 이었고, 이 주파수 에 대한 송파전압감도는 $161.50 \mathrm{~dB}$ 이었다. 또한, $-3 \mathrm{~dB}$ 에 대한 상한 주파수 $f_{1}$ 과 하한 주파수 $f_{2}$ 는 각각 $f_{1}=50.96 \mathrm{kHz}, f_{2}=48.80$ $\mathrm{kHz}$ 로서 기계적인 품질계수(quality factor), 즉, 공진 예리도 $\mathrm{Q}$ 는 $\mathrm{Q}=f_{S} /\left(f_{2}-f_{1}\right)=23.3$ 이었다. split beam 음향 변환기의 주파 수 대역폭, 즉 기계적인 품질계수 $\mathrm{Q}$ 가 낮을수록 해중으로 전파 되는 송신펄스신호의 파형은 진동자에 인가되는 전기적인 펄스 신호 파형과 유사한 형상을 나타낸다. 체장어군탐지기의 전기적 인 펄스신호는 구형 펄스신호(rectangular pulse signal)이기 때 문에 $\mathrm{Q}$ 값이 작은 경우, 개체어에 의한 echo 신호파형 역시 구형 에 유사한 파형을 나타내어 해중에 흩어져 분포하는 어류를 서 로 분리하여 탐지할 수 있는 능력이 향상될 뿐만 아니라 이들 어 류의 위치각의 측정 정도가 향상되어 반사강도 추정치의 신뢰도 를 향상시키는 요인이 된다.

\section{Split beam 음향 변환기의 수파감도}

Split beam 음향 변환기의 수파감도 $\mathrm{SRT}(\mathrm{dB}$ re $1 \mathrm{~V} / \mu \mathrm{Pa})$ 를 측정한 결과는 Fig. 7과 같다. Fig. 7에서 종축은 SRT $(\mathrm{dB})$ 이고, 횡축은 주파수 $(\mathrm{kHz})$ 이다. Fig. 7 의 SRT는 임의파형 발생기에서 출력되는 펄스폭 $1.25 \mathrm{~ms}$, 개시 주파수 $40 \mathrm{kHz}$, 주파수 대역폭 $20 \mathrm{kHz}$ 의 chirp 펄스신호가 R209 기준 송파기를 통해 송출될 때, 이 수중음향신호를 음축상 약 $1 \mathrm{~m}$ 의 거리에서 수중청음기 를 이용하여 수신한 chirp 펄스신호의 주파수 스펙트럼 $\left(H_{R}(f)\right)$ 과 본 연구에서 개발한 split beam 음향 변환기를 이용하여 같 은 위치에서 측정한 수신한 chirp 펄스신호의 주파수 스펙트럼 $\left(H_{T}(f)\right)$ 을 이용하여 다음 식으로부터 산출하였다.

$$
S R T(f)=M_{R}(f)+20 \log \left(\frac{H_{T}(f)}{H_{R}(f)}\right)
$$

여기서, $M_{R}(f)$ 는 표준 수중 청음기의 수파감도 $(\mathrm{dB}$ re $1 \mathrm{~V} / \mu P a)$ 이고, $f$ 는 주파수이다(Hughes et al., 1969; Hughes, 1998). Fig. 7에서 DR, DL, UR 및 UR 수신 진동자 블록에 대한 수파감도 의 주파수 의존성은 Fig. 5 (a)의 DR, DL, UR 및 UR 수신 진동 자 블록에 대한 conductance에 대한 주파수 의존성과 거의 유사 한 경향을 나타내고 있음을 알 수 있다.

Fig, 6에서 먼저 DR 수신 진동자 블록의 경우, 공진 주파수는 $49.98 \mathrm{kHz}$ 이었고, 이 주파수에 대한 SRT는 $-177.52 \mathrm{~dB},-3 \mathrm{~dB}$ 에 대한 상한 및 하한 주파수는 각각 $51.21 \mathrm{kHz}, 48.51 \mathrm{kHz}$ 로 서 주파수 대역 폭과 공진 예리도는 각각 $2.70 \mathrm{kHz}, 18.5$ 이었다. $\mathrm{DL}$ 수신 진동자 블록의 경우에는 공진주파수가 $\mathrm{DR}$ 블록과 같 이 $49.98 \mathrm{kHz}$ 이었으나, 이 주파수에 대한 SRT는 - $177.98 \mathrm{~dB}$ 로 


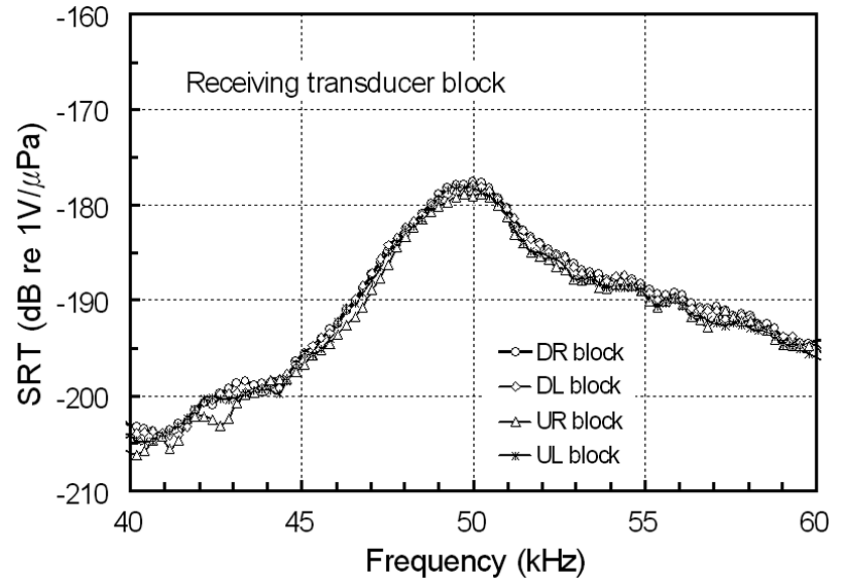

Fig. 7. Receiving sensitivity (SRT) for UL, UR, DL and DR quadrants of a developed $50 \mathrm{kHz}$ split beam transducer.

서 $\mathrm{DL}$ 블록과 약간의 차이를 나타내었다. 그러나, $-3 \mathrm{~dB}$ 에 대한 상한 및 하한 주파수는 DR 블록과 같이 각각 $51.21 \mathrm{kHz}, 48.51$ $\mathrm{kHz}$ 을 나타내어 주파수 대역 폭과 공진 예리도가 $\mathrm{DL}$ 블록과 동 일한 특성을 나타내었다. 한편, UR 수신 진동자 블록에 대한 공 진 주파수는 $49.74 \mathrm{kHz}$, 이 주파수에 대한 SRT는 $-178.91 \mathrm{~dB}$, $-3 \mathrm{~dB}$ 에 대한 상한 및 하한 주파수는 각각 $50.96 \mathrm{kHz}, 48.27$ $\mathrm{kHz}$ 로서 주파수 대역 폭과 공진 예리도는 각각 $2.70 \mathrm{kHz}, 18.5$ 이었다. UL 수신 진동자 블록에 대한 공진 주파수는 $49.49 \mathrm{kHz}$, 이 주파수에 대한 $\mathrm{SRT}$ 는 $-178.09 \mathrm{~dB},-3 \mathrm{~dB}$ 에 대한 상한 및 하 한 주파수는 각각 $50.96 \mathrm{kHz}, 48.51 \mathrm{kHz}$ 로서 주파수 대역 폭과 공진 예리도는 각각 $2.45 \mathrm{kHz}, 20.2$ 이었다. Fig. 7에서 DR, DL, $\mathrm{UR}$ 및 $\mathrm{UR}$ 의 수신 진동자 블록에 대한 공진 주파수는 설계 목 표치인 $50 \mathrm{kHz}$ 에 매우 근사한 특성을 나타내었고, 이들 각 진동 자 블록에 대한 수파감도는 Fig. 5에서 수신 진동자 블록에 대한 conductance의 변화에 비례하여 변화하는 특성을 나타내었다. 특히, 수파감도가 가장 높은 DR 블록과 가장 낮은 UR 블록 사 이의 차는 $1.39 \mathrm{~dB}$, 또한, $\mathrm{DR}, \mathrm{DL}, \mathrm{UL}$ 블록 사이에는 거의 유사 한 수신감도특성을 나타내어 현장에서의 반사강도 측정 및 체장 추정에 실용적으로 활용될 수 있는 성능을 갖추고 있다고 평가 된다.

\section{Split beam 음향 변환기의 지향특성}

본 연구에서는 먼저 sidelobe를 효과적으로 억제하기 위해 직 경 $12 \mathrm{~mm}$ 의 $50 \mathrm{kHz}$ tonpilz형 진동소자를 먼저 개발하고, 이들 을 반파장 간격으로 평면 배열한 후, 목적하는 sidelobe 레벨을 도출하기 위해 Dolph-Chebyshev 가중치설계 기법에 의한 수 치 시뮬레이션을 반복적으로 수행하였다. 이 시뮬레이션을 통 해 최종적으로 얻어진 가중치로부터 산출된 시뮬레이션 결과 는 Fig. 8과 같다. Fig. 8은 $6 \times 6$ 평면 배열 패턴에서 사각의 네 모서리에 위치하는 진동 소자를 하나씩 제거한 총 32개로 구성 되는 원형에 유사한 배열형상을 대상으로 sidelobe 레벨의 설계 목표치를 $-30 \mathrm{~dB}$ 로 하여 얻어진 결과이다. Fig. 8(a)는 송신 빔 의 3 차원 형상을 나타낸 것이고, (b)는 등감도 레벨의 countor를 나타낸 결과이다. Fig. 8에서 알 수 있는 바와 같이 설계 목표치 로 설정한 $-30 \mathrm{~dB}$ 이 제 1 의 sidelobe에서 나타나고 있고, 그 밖 의 모든 sidelobe가 제 1 의 sidelobe 보다 낮은 레벨로서 나타나 고 있음을 알 수 있다. 따라서, 본 연구에서는 Fig. 8의 시뮬레이 션 결과를 도출하는데 적용된 각 진동소자에 대한 가중치를 이 용하여 가중 transformer를 자체적으로 설계, 제작하고, 이들 transformer를 32개의 진동소자에 각각 접속하여 완성한 Fig. 4 의 split beam 음향 변환기를 대상으로 송신 지향성 패턴의 이론 치 및 실험치를 비교한 결과는 Fig. 9와 같다.

Fig. 9에서 수평(정횡방향) 방향에 대한 송파지향성 패턴의
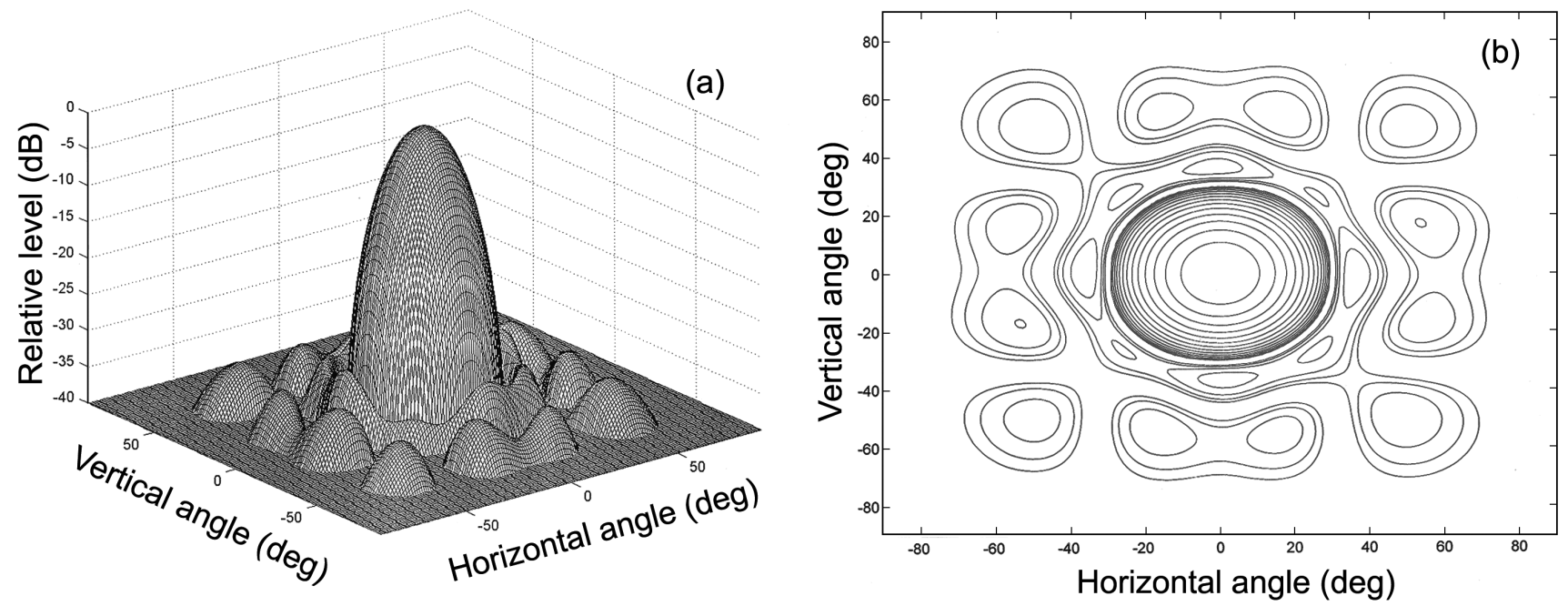

Fig. 8. Theoretical transmission beam pattern (a) and contour view of equal sensitivity in sound beam (b) for a $50 \mathrm{kHz}$ split-beam transducer shaded by the Dolph-Chebyschev weighting method. A design goal of side lobe level was $-30 \mathrm{~dB}$. 

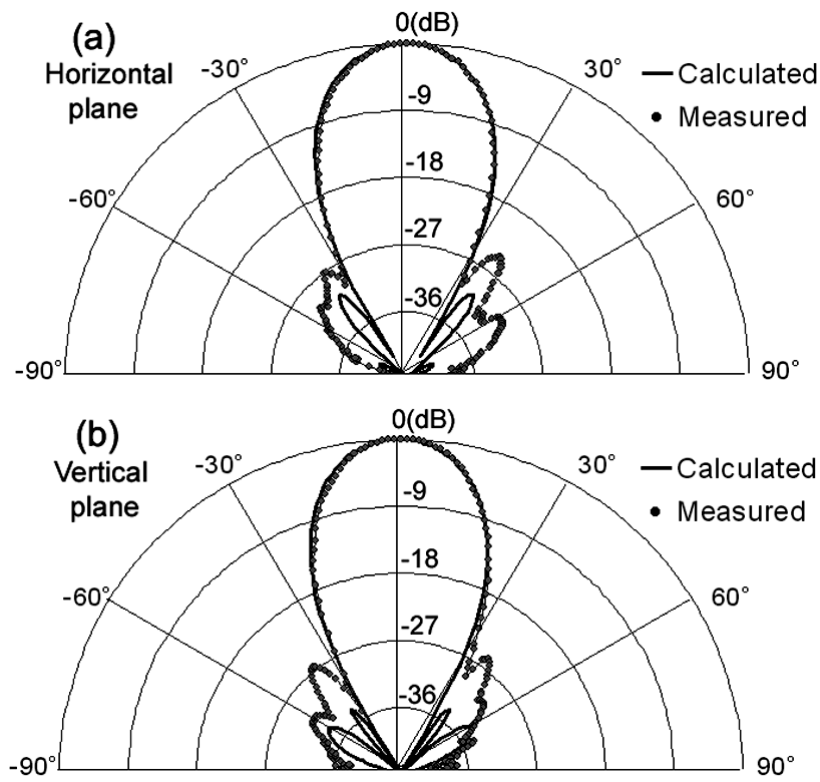

Fig. 9. Measured transmission beam patterns in horizontal (a) and vertical planes (b) for a developed $50 \mathrm{kHz}$ split-beam transducer consisting of 32 elements with one element in each corner missing.

실험치와 이론치를 비교한 결과는 Fig. 9(a)와 같고, 수직 (선수 방향) 방향에 대한 송파지향성 패턴의 실험치와 이론치를 비교 한 결과는 Fig. 9(b)와 같다. Fig. 8과 Fig. 9에서 수치 시뮬레이 션에 대한 $-3 \mathrm{~dB}$ 점의 수평 및 수직 방향에 대한 빔 폭과 실험에 의해 측정한 빔 폭은 서로 잘 일치하였고, 그 값은 수평 및 수직
방향에서 모두 $21.0^{\circ}$ 이었다. 그러나, 수평 및 수직 방향에 있어 제 1 sidelobe 레벨은 측정치가 수치 시뮬레이션 결과 보다 더 큰 경향을 나타내었다. 즉, 수평방향의 경우, 수치 시뮬레이션에 대 한 제 1 sidelobe에 대한 방향각과 레벨은 각각 $38.0^{\circ},-30.93 \mathrm{~dB}$ 과 $-37.0^{\circ},-30.96 \mathrm{~dB}$ 이었지만, 실험적인 지향성 패턴에 있어서 의 제 1 sidelobe에 대한 방향각과 레벨은 각각 $37.0^{\circ},-24.70 \mathrm{~dB}$ 과 $-36.0^{\circ},-27.20 \mathrm{~dB}$ 으로서 설계 목표치 $-30 \mathrm{~dB}$ 보다 $5.4 \mathrm{~dB}$ 과 $2.8 \mathrm{~dB}$ 각각 더 높은 값을 나타내었다. 한편, 수직방향에 있어서 수치 시뮬레이션에 대한 제 1 sidelobe에 대한 방향각과 레벨은 각각 $36.0^{\circ},-34.29 \mathrm{~dB}$ 과 $-36.0^{\circ},-34.29 \mathrm{~dB}$ 로서 서로 같았지만, 측정된 지향성 패턴에 있어서의 제 1 sidelobe에 대한 방향각과 레벨은 각각 $37.0^{\circ},-25.59 \mathrm{~dB}$ 과 $-38.0^{\circ},-26.64 \mathrm{~dB}$ 로서 설계 목 표치 $-30 \mathrm{~dB}$ 보다 $4.4 \mathrm{~dB}$ 과 $3.4 \mathrm{~dB}$ 각각 더 높은 값을 나타내었 다. 이들의 결과는 설계 목표치 $-30 \mathrm{~dB}$ 보다 약간 높은 sidelobe 레벨이지만, 수평 및 수직방향에 있어서의 sidelobe 레벨을 - 25 $\mathrm{dB}$ 이하로 억제시킴으로서 현장에서 위상각 검출하는데 필요한 $\mathrm{SNR}$ 은 충분히 확보되었다고 판단된다.

한편, split beam 음향 변환기의 4 분할 진동자 $\mathrm{UL}, \mathrm{UR}, \mathrm{DL}$ 및 DR 블록에 대한 수신지향특성을 측정한 결과는 Fig. 10과 같 다. Fig. 10 에서 먼저 $\mathrm{UL}$ 진동자 블록의 $-3 \mathrm{~dB}$ 점에 대한 지향 각은 $30.2^{\circ}$, 수신빔의 음축 offset는 $-0.21^{\circ},-3 \mathrm{~dB}$ 지향각 범위는 $-15.97^{\circ}-+14.24^{\circ}$ 이었고. UR 진동자 블록의 $-3 \mathrm{~dB}$ 점에 대한 지 향각은 $31.0^{\circ}$, 수신빔의 음축 offset는 $-0.65^{\circ},-3 \mathrm{~dB}$ 지향각 범위 는 $-17.05^{\circ}-+14.03^{\circ}$ 이었다. 한편, $\mathrm{DL}$ 진동자 블록의 $-3 \mathrm{~dB}$ 점 에 대한 지향각은 $31.9^{\circ}$, 수신빔의 음축 offset는 $0.65^{\circ},-3 \mathrm{~dB}$ 지 향각 범위는 $-9.71^{\circ}-+22.23^{\circ}$ 이었고, $\mathrm{DR}$ 진동자 블록의 $-3 \mathrm{~dB}$
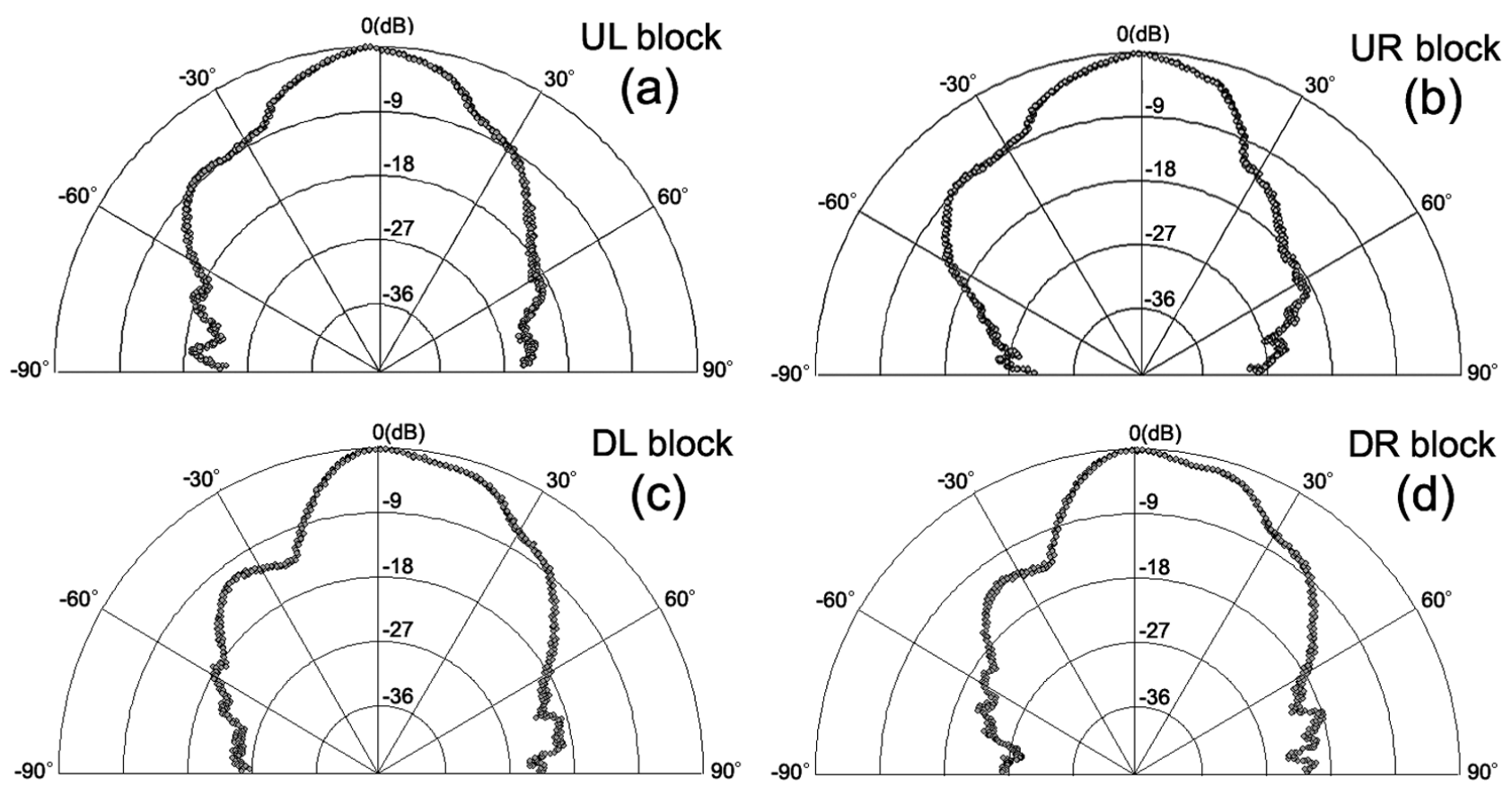

Fig. 10. Measured reception beam patterns for UL, UR, DL and DR quadrants shaded by using the transformer to obtain the spacing of approximately one wavelength between acoustic centers in a developed $50 \mathrm{kHz}$ split-beam transducer. 
점에 대한 지향각은 $32.36^{\circ}$, 수신빔의 음축 offset는 $0.21^{\circ},-3 \mathrm{~dB}$ 지향각 범위는 $-10.07^{\circ}-+22.29^{\circ}$ 이었다. Fig. 10에서 알 수 있는 바와 같이 4 분할 진동자 블록의 수신 지향성패턴의 형상, 지향 각 및 offset를 서로 비교하여 볼 때, UL의 특성은 UR과 거의 같 고, $\mathrm{DL}$ 의 특성은 $\mathrm{DR}$ 과 거의 같다. 이와 같은 패턴은 향후 이 변 환기를 선박에 장착할 때, UL과 UR 블록은 좌현 정횡에 선수미 선과 평행하게, 또한, DL과 DR 블록은 우현 정횡에 선수미선 과 평행하게 설치한다는 음향 변환기의 선저 수납조건을 설정하 여 지향성을 측정하였기 때문이다. 즉, 수신지향성을 측정할 때, 음향수조의 한쪽 끝단으로부터 현수된 송파용 초음파 진동자 를 turntable의 회전축에 고정한 후, 송파 진동자에서 보았을 때, $\mathrm{UR}$ 과 UL 블록은 우측의 상하위치에, DR과 DL 블록은 좌측의 상하위치에 배치되도록 사전에 음향 변환기의 자세를 교정하였 다. 이 때문에 UL과 UR 블록, 또한, DL과 DR 블록은 같은 수신 지향성 패턴으로 나타내고 있는 것이다.

\section{음향 변환기의 송수신 펄스응답특성}

본 연구에서 개발한 $50 \mathrm{kHz}$ split beam 음향 변환기의 송신 펄스신호의 시간응답특성은 Fig. 11과 같다. Fig. 11의 펄스응답 신호는 음향 변환기에 펄스폭 $0.5 \mathrm{~ms}$ 의 구형 펄스신호를 인가하 고, 음축상 약 $2.5 \mathrm{~m}$ 의 거리에서 수중청음기를 이용하여 변환기 로부터 송출되는 직접파 신호를 수신한 결과이다. Fig. 11에서 알 수 있는 바와 같이 응답 펄스신호는 전단부(rising edge)에서

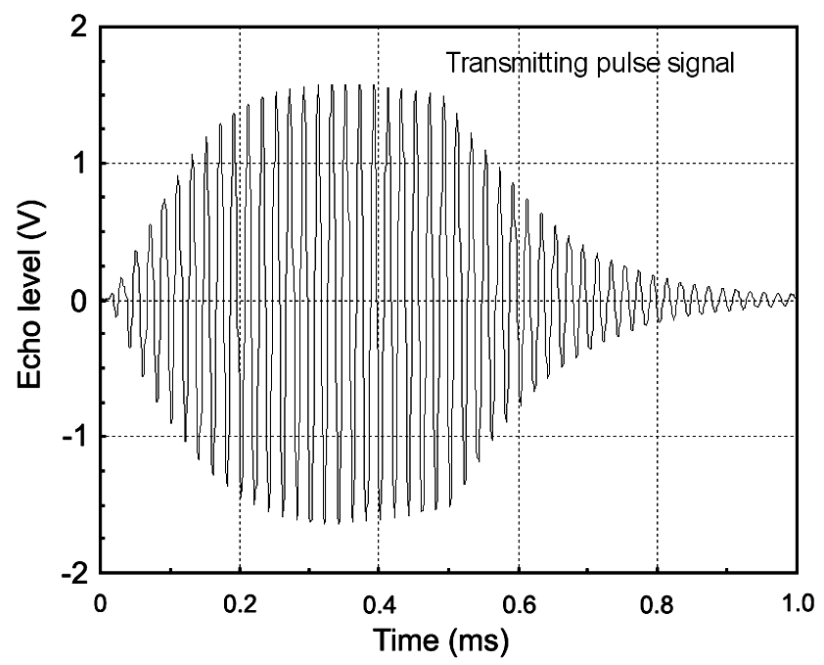

Fig. 11. Transmitting pulse signal from a developed $50 \mathrm{kHz}$ splitbeam transducer measured by using B\&K 8105 hydrophone.

는 비교적 가파르게 상승하고 있으나 후단부(falling edge)에 있 어서는 비교적 완만하게 하강하여 긴 꼬리부분이 나타나고 있음 을 알 수 있다. Fig. 12로부터 측정된 펄스신호의 상승시간(rise time)은 $0.182 \mathrm{~ms}$ 이었고, 하강시간(fall time)은 $0.513 \mathrm{~ms}$ 로서 하강시간이 상승시간보다 약 2.8 배 더 긴 특성을 나타내었다.
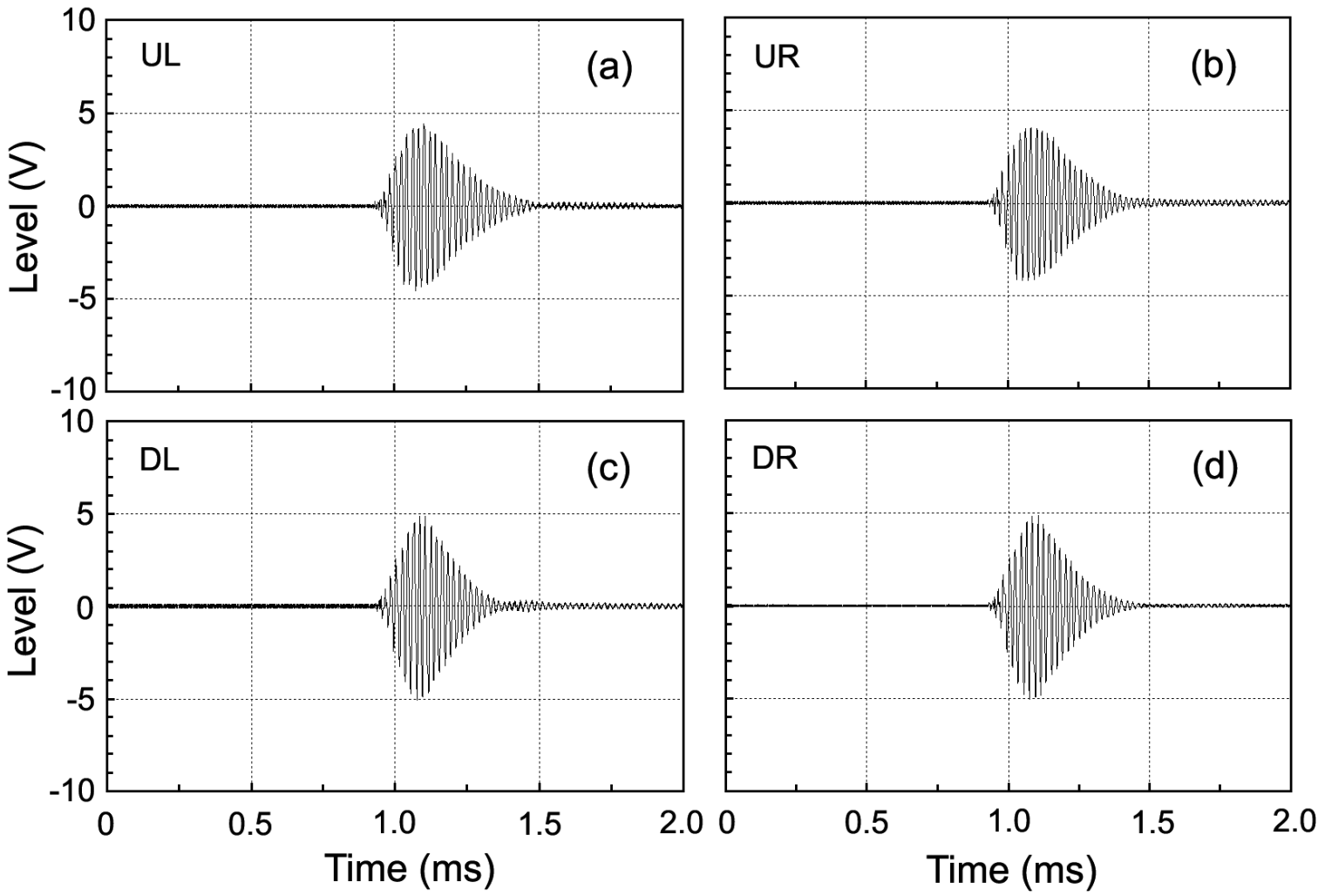

Fig. 12. Receiving pulse responses for UL, UR, DL and DR quadrants of a developed $50 \mathrm{kHz}$ split-beam transducer. The pulse signal was transmitted from a $50 \mathrm{kHz}$ ultrasonic pinger developed to test the transducer. 
한편, split beam 음향 변환기의 4 분할된 수신 진동자 블록 $\mathrm{UL}, \mathrm{UR}, \mathrm{DL}$ 및 DR에 대한 수신펄스신호의 시간응답특성을 조 사한 결과는 Fig. 12과 같다. 여기서는 수신응답특성을 조사하 기 위해 $50 \mathrm{kHz}$ 용 수중 초음파 핑거를 자체 제작한 후, 이것을 split beam 음향 변환기의 음축상에 설치하고, 핑거로부터 발사 되는 초음파신호를 각 수신진동자 블록을 통해 수신한 결과이 다. Fig. 12에서 4 분할 수신 진동자 블록 UL, UR, DL 및 DR에 의한 수신신호는 각 진동자 블록의 수파감도에 비례하는 전압레 벨을 나타내어 그 수신응답특성이 매우 양호함을 알 수 있다. 즉, Fig. 12에서의 UL, UR, DL, DR 수신 진동자 블록에 대한 전압 레벨은 각각 $4.39 \mathrm{~V}, 4.12 \mathrm{~V}, 4.87 \mathrm{~V}, 4.89 \mathrm{~V}$ 로서 이들 수신전압 레벨은 수파감도에 비례하여 출력되고 있음을 알 수 있었다.

일반적으로 수중 음향 변환기는 기계적 품질계수가 작을수 록, 즉 주파수 대역폭이 넓을수록 송신펄스신호의 전반부에 대 한 상승시간과 후반부에 대한 하강시간이 짧아지는 펄스응답특 성을 나타낸다. 특히, 이들 상승과 하강시간을 짧게 제어하면 어 류에 의해 산란되는 echo 신호의 후반부에 긴 꼬리 모양으로 나 타나는 신호의 ringing 현상이 크게 억제되기 때문에 개체어를 서로 분리하여 탐지 및 식별할 수 있는 거리 분해능이 향상되고, 또한, 해저나 인공 어초와 같은 수중물표 부근에 인접하여 분포 하는 어류나 어군을 해당 물표와 분리하여 식별할 수 있는 탐지 성능을 향상시킬 수 있다. 이 때문에 많은 연구자들은 음향 변환 기의 대역폭을 증대시키기 위한 연구를 활발하게 수행하고 있 고, 본 연구에서도 개발된 split beam 음향 변환기의 대역폭을 더욱 확장시켜 펄스신호의 후단부에 나타나는 긴 꼬리모양의 ringing time을 최소화시키기 위한 연구를 현재 수행 중에 있다.

\section{사 사}

이 논문은 2009년도 정부(교육과학기술부)의 재원으로 한 국연구재단의 지원을 받아 수행된 기초연구사업임(No. 20090071881).

\section{참고문헌}

Balanis CA. 1997. Antenna Theory. John Wiley \& Son Inc, New York, U.S.A., 294-306.

Dolph, CL. 1946. A current distribution for broadside arrays which optimizes the relationship between beam width and side-lobe level. Proc of the IRE 34, 335-348.

Ehrenberg JE. 1981. Analysis of a split beam backscattering cross section estimation and single echo isolation technique. APL-UW 8108, 1-24.
FAO. 2009. Report of the expert consultation on international guidelines for bycatch management and reduction of discards. FAO fisheries and aquaculture report No. 934. 1-37.

Foote KG. 1990. Designing an improved transducer array geometry. J Cons int Explor Mer 46, 129-132.

Hughes WJ. 1998. Transducer, underwater acoustic. Encyclopedia of applied physics 22, 67-84.

Hughes WJ and Zipparo MJ. 1969. Computer modeling of ultrasonic piezoelectric transducers. Technical report No TR 96-007, Applied Research Lab, The Pennsylvania State Univ, Pennsylvania, U.S.A., 1-116.

Lee DJ and Shin HI. 2001. Development of a split beam transducer for measuring fish size distribution. Bull Korean Soc Fish Tech 37, 196-213.

Lee DJ and Lee WS. 2010. Design, fabrication and performance characteristics of a $50 \mathrm{kHz}$ tonpilz type transducer with a half-wavelength diameter. J Kor Soc Fish Tech 46, 173-183.

MacLeannan DN and Simmonds EJ. 1995. Fisheries Acoustics. Chaman \& Hall, London, U.K., 45-88.

Park HY, Kim MJ, Lee DJ, Yoon JR, Kim CD and Abe M. 2004. Split-beam method for fish finder using a bandlimited sweep signal. ICA 2004, 759-760.

Quaji AH. 1982. Array beam response in the presence of amplitude and phase fluctuations. J Acoust Soc Am 72, 171-180.

Sawada K, Takao Y, Takahashi H, Abe K, Okumura K, Kobayashi A and Sugimoto M. 2004. Development of an acoustic-optical system (J-QUEST) for fisheries surveysI . -Acoustic system-. Tech Rep Nat Res Inst Fish Eng 26, 23-33.

Simrad AS. 2008. 70 kHz split-beam transducer. ES 70-11 catalog, 1-2.

Wilson OB. 1991. Introduction to Theory and Design of Sonar Transducers. Peninsula Publishing, California, U.S.A., 11108.

Ziomeck LJ. 1985. Underwater Acoustics. Academic Press Inc, New York, U.S.A., 94-152.
2011년 4월 12일 접수

2011년 5월 11일 수정

2011년 7월 27일 수리 